\title{
A Study About The Nature Of Science's Effect On The Pre-Service Science Teachers' Informal Reasoning About Global Warming
}

\author{
Baris Eroglu \\ Aksaray University, Department of Primary Education, Aksaray \\ Email: bariserogl@gmail.com \\ Mustafa Aydogdu
}

Gazi University, Department of Science Education, Ankara

Doi:10.5901/ajis.2013.v2n3p297

\begin{abstract}
The purpose of this study is to reveal how the pre-service science teachers conceptualize the nature of science in their informal reasoning, regarding the subject of global warming. In line with this purpose, case study was selected among the qualitative study approaches in this research. The study was conducted in two phases. Firstly, 38 sophomore pre-service science teachers, who were receiving education at a state university, were determined and their conceptualizations regarding the nature of science were attained. Following the analyses, four pre-service science teachers were selected among 38 pre-service science teachers and the second phase started. In this phase, a research was performed to find out how the conceptualizations about nature of science of these four pre-service science teachers affect their informal reasoning processes. Descriptive analysis and content analysis were used for the data analyses. According to the findings, it was revealed that pre-service science teachers have difficulty with defining the scientific data about the global warming, which is a socioscientific issue, in their informal reasoning processes and that they qualify experiment and observation as the basic elements of science. The general opinion is that the scientific knowledge might change under the influence of various factors. On the other hand preservice science teachers cannot suggest a clear idea about cultural and social embeddedness of science and they are in a result-based informal reasoning process about this issue.
\end{abstract}

Keywords: Nature of science, socioscientific issues, pre-service science teacher, global warming, informal reasoning

\section{Introduction}

There is a complex relationship between science and society. Generally scientific developments shape through the society's needs, also society shapes itself to benefit from these developments. The issues in which the complex interaction between science and society is discussed are called "socio-scientific issues" (SSI) (Fleming, 1986; Kolstø, 2001; Zeidler, Walker, Ackett, and Simmons, 2002).

Intentions about the education for SSI is that considering moral judgments about ethical and scientific issues via social interaction and argumentation. SSI requires scientific process or produces, and provides a social argumentation (Sadler and Zeidler, 2005).

Zeidler et al. (2002, p.344) mention that SSI is a term that it includes all the classification of Science-Technology and Society (STS) and also considers the ethical dimensions of science, the moral reasoning 0 a child and students emotional developments. Recently the researches about SSI include biotechnological developments and applications like cloning, stem cell technology and genetically modified foods (GMFs) (Sadler, 2003; Topçu, 2008; Zohar and Nemet, 2002) or environmental issues like global climate change (Bell and Lederman, 2003; Sadler, Chambers, and Zeidler, 2004; Topçu, 2008).

Although the results of scientific researches are presented with terms of formal reasoning and logic, informal reasoning lays basis of these results in details (Tweney, 1991). While the premises of informal reasoning are changeable with new added information, formal reasoning's are stable and constant. Besides the results of formal reasoning are inevitably byproducts, but in informal reasoning results are not clear and unexpected. The issues dealt with informal reasoning don't have any lucid and short results and people are focused to plus and minus of the situations, alternatives, reasons and results (Means and Voss, 1996; Zohar and Nemet, 2002).

In literature it can be seen different results and implications from researches about nature of science (NOS) effects 
on the individual's informal reasoning about SSI. It has been put forward that the relations between scientific knowledge and scientific knowledge's experimental evidences within the related society (Zeidler et al., 2002). Besides in some researches it can be found that individuals give little place to NOS in their informal reasoning (Bell and Lederman, 2003) or individuals think that there is a relation between social nature of scientific knowledge and informal reasoning (Sadler et al., 2004). Also Walker and Zeidler (2007) found that students don't reflect their views about NOS in the classroom discussions.

The purpose of this study is to reveal how pre-service science teachers conceptualize three specified aspects of NOS (the tentativeness of scientific knowledge, the empirical basis of scientific knowledge, and the social and cultural embeddedness of scientific knowledge) in their informal reasoning, regarding the subject of global warming.

\section{Design and Procedures}

Case study, one of the qualitative research designs was used for this study. This study was carried out by two steps. First it was revealed that pre-service science teacher' conceptualizations about specified elements of nature of science (tentativeness, empirical basis, and social cultural embeddedness). Then for the second step it was tried to reveal that how NOS effects pre-service science teachers' informal reasoning about global warming. Participants determined with purposeful sampling method in different steps of this study. First criteria sampling used for determination of the classrooms which will be used in this study? Criterias used for this research are;

- The participants of this study must be undergraduate program called "science education",

- The participants of this study must be not taken the history and philosophy of science course (because it can manipulate pre-service science teachers' views about NOS).

The study includes two different sophomore classes from science education program. With one of them pilot studies and with the other one main study carried out. Pre-service science teachers's views about NOS elements revealed with the open-ended questionnaires that Lederman, Abd-El-Khalick, Bell, and Schwartz (2002) produced. Secondly to reveal the relations among global warming, NOS conceptualizations, and informal reasoning "the fictitious science briefs" was produced by Sadler et al. (2004) was used. For this study credibility and thrustworthiness provided with triangulation of multiple data sources. The data was analyzed with "descriptive statistic" approach. In Figure 1. you can see the summary of the design and method procedures of this study.

Figure 1. Summary of the Research Design

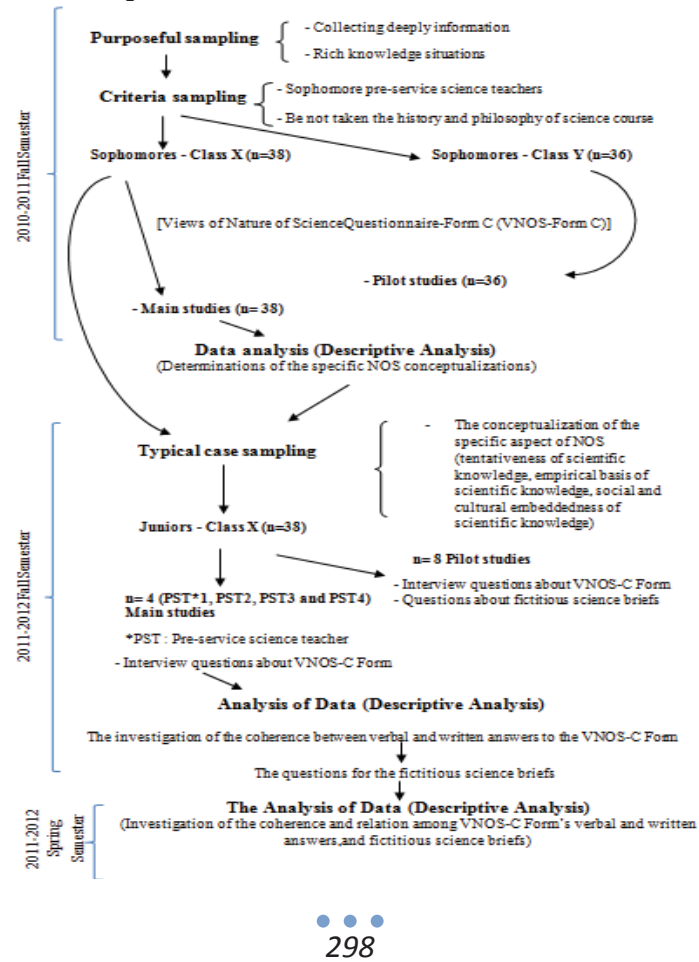




\section{Results and Discussion}

\subsection{The Results about Pre-Service Science Teachers' Conceptualizations about Empirical Basis of the Scientific Knowledge}

In order to fully appreciate the empirical nature of science, an individual must understand what constitute data and how can it be used. One can say that scientific knowledge bases on the empirical evidence but if one cannot understand that what data is his claim will not make sense (Sadler et al., 2004, p.393). In this study it was revealed that pre-service science teachers struggled with identifying what data is. Instead of identifying what data is, the pre-service science teachers just abstracting the fictitious science briefs.

According to the results all the four pre-service science teachers had consensus about that with the experiment, concepts can turn into tangible from intangible. This can be considered as a positive effect on the regarded issue. The pre-service science teachers think that experiments ease understanding about the issue, and this can lead to the permanent learning.

Pre-service science teachers indicated that experimental studies can be used as a verification tool for the determination of the scientific knowledge's accuracy. But this is one of the most commonly encountered naïve views about the empirical basis of scientific knowledge. As McCommas (2002) pointed out that scientist are so busy to do verification like that and research foundations are inadequate to support this situation.

Pre-service science teachers described that experiment and observations are the basic elements of science. Also they indicated that experiments are paths to the unknown, and it can be reached to exact information per experiments. Experiments have important roles about reaching to the scientific knowledge but they are not sole. In some scientific areas (like astronomy) you can't manipulate the variables related with subject (McCommas, 2002).

Pre-service science teachers who attended to this study indicated that quantitative variables have direct relationship with the scientific knowledge. Pre-service science teachers remarked the difference between scientific and daily knowledge because of scientific knowledge includes quantitative data. Walker, Zeidler, Simmons, and Ackett (2000) showed that students determined the difference between scientific knowledge and ordinary idea from the point of subjectivity and objectivity. According to the students scientific knowledge must have objective, and the other knowledge types must have subjective character. Meanwhile in the same study, students interpreted that scientific knowledge are proved, and tested; the other thoughts and ideas have personal and emotional characters.

Pre-service science teachers remarked that scientists use their imaginations and creativity during the experimental process. Walker et al. (2000) found that high school and college students believed that science includes creativity but also students think that science as a "clinical process" for the oncoming years during the education because of the rote.

\subsection{The Results about Pre-Service Science Teachers' Conceptualizations about the Tentativeness of Scientific Knowledge}

According to the results of this study pre-service science teachers hold naïve views about theory definitions. Pre-service science teachers indicated that theories are the temporal solution mechanisms and they are statements that there is no evidence about trueness and fallaciousness for them.

Four pre-service science teachers were like-minded about that theories have changeable structures. But when this idea deeply investigated, it was revealed that they had naïve views about this subject. Because pre-service science teachers thought that theories can turn into laws. Pre-service science teachers' views about theories showed themselves more apparently during VNOS-C interview sessions. Walker et al. (2000) showed that high school and college students have ideas about this issue in a wide spectrum. Some of the students identified that theories cannot change and have static structures; some of them thought that they can change with technology, and some of them said that they have changeable character.

From the results of this study all of the four pre-service science teachers thought that laws are stable, and can't change. They thought also laws can be provable. This situation overlaps with the myth that McCommas (2002) indicated that people have naïve views about the tentativeness of scientific knowledge and they were confused to distinguish the meanings of scientific and mathematical proofs.

In this study about the effects of one of the NOS element "tentativeness of scientific knowledge" on the pre-service science teachers' informal reasoning process it was revealed that scientific knowledge could be change with the effects of the different factors. Pre-service science teachers indicated that because of the scientists have different a priori 
knowledge, observation skills, value judgments, perspectives, cultural values, and also curiosity and doubt could cause the changes for the scientific knowledge.

Besides according to this research's results, pre-service science teachers thought that economy and environmental factors can have effects on the change of scientific knowledge. Walker et al. (2000) revealed that most of the students were surprised about the scientists who work with the same data but reach different results and some college students thought that scientist can manipulate data to fit them into their beliefs. And also students thought that because of the different sets of data, and differences between scientists' theories and minds can be the reasons to reach different conclusions of scientists.

\subsection{The Results about Pre-Service Science Teachers' Conceptualizations about the Social and Cultural Embeddedness of Scientific Knowledge}

According to the study results all of the four pre-service science teachers held no clear idea about embracing social and cultural life with scientific knowledge. Pre-service science teachers thought that scientific knowledge must have a universal structure without effecting from social and cultural life. But they thought also scientific knowledge may have a relation between social and cultural life. There is similarity between literature in terms of results. Lederman, Abd-ElKhalick, Bell and Schwartz (2002) found similar naïve and informed views about scientific knowledge just as this study's. For example in this study one of the pre-service science teachers gave some examples about a scientist who punished because of his interpretations about astronomy. Lederman et al. (2002) found similar results like that one of the respondents said that Copernicus punished by church because of his ideas about astronomy.

\section{Suggestions}

In this study it was found that pre-service science teachers have a "result-pointed" thinking structure about social and cultural embeddedness of science. Pre-service science teachers thought that science must be universal, and couldn't show any differences among societies. But also they indicated that during the process of scientific enterprise it can be different interaction between science and the society where science occurs. Pre-service science teachers commented about the definite situation of scientific enterprise rather than its creational and developmental process. Because of this reason for further studies "developmental process of science" should be considered and emphasized.

Khishfe (2012) found that the students who obtained some NOS understandings about the issue genetically modified foods (GMFs) can transfer their NOS understandings to a new issue called "fluoridation of drinking water". We can see here is that students can transfer their NOS understanding to a new topic that they met for the first time. So here it can be said that some NOS aspects are independent from the issues that we dealt with. If we can provide some understandings about NOS for the students we can reveal that how they transfer these understandings and which factors affect their understandings.

\section{References}

Bell, R. L., \& Lederman, N. G. (2003). Understandings of the nature of science and decision making on science and technology based issues. Science Education, 87 (3), 352-377.

Fleming, R. (1986). Adolescent reasoning in socio-scientific issues. Part I: Social cognition. Journal of Research in Science Teaching, 23, 677-687.

Khishfe, R. (2012). Transfer of nature of science understandings into similar context: Promises and possibilities of an explicit reflective approach. International Journal of Science Education .

Kolsto, S. D. (2001). Scientific literacy for citizenship: Tools for dealing with the science dimension of controversial socioscientific issues. Science Education, 85, 291310.

McComas, W. F. (2002). The principal elements of the nature of science: Dispelling the myths. In W. F. McComas (Ed), The nature of science in science education. Rationales and strategies (s. 53-70). Dordrehct: Kluwer Academic Publishers.

Means, M. L., \& Voss, J. F. (1996). Who reasons well? Two studies of informal reasoning among children of different grade, ability, and knowledge levels. Cognition and Instruction, 14 (2), 139-178.

Lederman, N. G., Abd-El-Khalick, F., Bell, R. L., \& Schwartz, R. S. (2002). Views of nature of science questionnaire: Toward valid and meaningful assessment of learners' conceptions of nature of science. Journal of Research in Science Teaching, 39(6), 497-521.

Sadler, T. D., \& Zeidler, D. L. (2005). Patterns of informal reasoning in the context of socioscientific decision making. Journal of Research in Science Teaching, 42 (1), 112-138.

Sadler, T. D., Chambers, F. W., \& Zeidler, D. L. (2004). Students conceptualizations of the nature of science in response to a 
socioscientific issue. International Journal of Science Education, 26, 387-409.

Sadler, T. D. (2003). Informal reasoning regarding SSI: Their influence on morality and content knowledge. Unpublished doctoral dissertation. Florida.

Topçu, M. S. (2008). Preservice science teachers' informal reasoning regarding socioscientific issue and the factors influencing their informal reasoning. Unpublished doctoral dissertation. Middle East Technical University, Ankara.

Tweney, R. D. (1991). Informal reasoning in science. In J. F. Voss, D. N. Perkins, \& J. W. Segal (Eds.), Informal reasoning and education (s. 3-16). Hillsdale, NJ: Erlbaum.

Walker, K. A., \& Zeidler, D. L. (2007). Promoting dicsourse about SSI through scaffolded inquiry. International Journal of Science Education, 29 (11), 1387-1410.

Walker, K. A., Zeidler, D. L., Simmons, M. L., \& Ackett, W. A. (2000). Multiple views of the nature of science and socio-scientific issues. Annual Meeting of the American Educational Research Association (AERA). New Orleans, LA.

Zeidler, D. L., Walker, K. A., Ackett, W. A., \& Simmons, M. L. (2002). Tangled up in views: Beliefs in the nature of science and responses to socioscientific dilemmas. Science Education, 86, 343-367.

Zohar, A., \& Nemet, F. (2002). Fostering students' knowledge and argumentation skills through dilemmas in human genetics. Journal of Research in Science Teaching, 39, 35-62. 
